\title{
Chloroplast Genome Sequence of Clusterbean (Cyamopsis tetragonoloba L.): Genome Structure and Comparative Analysis
}

\author{
Tanvi Kaila ${ }^{1,+}$, Pavan K. Chaduvla ${ }^{1,+}$, Hukam C. Rawal ${ }^{1}$, Swati Saxena ${ }^{1}$, Anshika Tyagi ${ }^{1}$, \\ S. V. Amitha Mithra ${ }^{1}$, Amolkumar U. Solanke ${ }^{1}$, Pritam Kalia ${ }^{2}$, T. R. Sharma ${ }^{1,3}$, N. K. Singh ${ }^{1}$ \\ and Kishor Gaikwad ${ }^{1, *}$ \\ 1 ICAR-National Research Centre on Plant Biotechnology, New Delhi 110012, India; \\ tanvii88@gmail.com (T.K.); pavanraaz@gmail.com (P.K.C.); hukam.rawal@gmail.com (H.C.R.); \\ swatisaxena605@gmail.com (S.S.); tyagi.anshika9@gmail.com (A.T.); \\ amithamithra.nrcpb@gmail.com (S.V.A.M.); amolsgene@gmail.com (A.U.S.); \\ trsharma1965@gmail.com (T.R.S.); nksingh@nrcpb.org (N.K.S.) \\ 2 Division of Vegetable Sciences, Indian Agricultural Research Institute, Pusa, New Delhi 110012, India; \\ pritam.kalia@gmail.com \\ 3 National Agri-Food Biotechnology Institute (NABI), Mohali, Punjab 140306, India \\ * Correspondence: kish2012@nrcpb.org \\ $\dagger$ These authors contributed equally to this work.
}

Academic Editor: Aureliano Bombarely

Received: 18 July 2017; Accepted: 21 August 2017; Published: 25 August 2017

\begin{abstract}
Clusterbean (Cyamopsis tetragonoloba L.), also known as guar, belongs to the family Leguminosae, and is an annual herbaceous legume. Guar is the main source of galactomannan for gas mining industries. In the present study, the draft chloroplast genome of clusterbean was generated and compared to some of the previously reported legume chloroplast genomes. The chloroplast genome of clusterbean is $152,530 \mathrm{bp}$ in length, with a quadripartite structure consisting of large single copy (LSC) and small single copy (SSC) of $83,025 \mathrm{bp}$ and 17,879 bp in size, respectively, and a pair of inverted repeats (IRs) of 25,790 bp in size. The chloroplast genome contains 114 unique genes, which includes 78 protein coding genes, 30 tRNAs, 4 rRNAs genes, and 2 pseudogenes. It also harbors a $50 \mathrm{~kb}$ inversion, typical of the Leguminosae family. The IR region of the clusterbean chloroplast genome has undergone an expansion, and hence, the whole rps19 gene is included in the IR, as compared to other legume plastid genomes. A total of 220 simple sequence repeats (SSRs) were detected in the clusterbean plastid genome. The analysis of the clusterbean plastid genome will provide useful insights for evolutionary, molecular and genetic engineering studies.
\end{abstract}

Keywords: clusterbean; Leguminosae; chloroplast genome; Illumina Hiseq 1000 platform; codon usage; microsatellites

\section{Introduction}

Clusterbean (Cyamopsis tetragonoloba L.), also known as guar, is an annual herbaceous legume, tolerant to drought and salinity [1-3]. It belongs to the family Leguminosae and subfamily Papilionoideae. Due to its short growing season (90-120 days) [4], it is grown in rotation with other crops, like cotton, grain, sorghum, flax, etc. [5,6]. Guar also increases the nitrogen content and organic matter of the soil by the process of nitrogen fixation, and hence, leads to the increase in yield of other crops grown in rotation with it [6-8]. Guar is primarily cultivated in arid and semi-arid regions, like North-West India and South-East Pakistan. Guar pods are consumed as vegetables across the globe as they are a rich source of minerals, fibres, proteins and Vitamin C [9]. 
Guar is the main source of galactomannan for industries [10]. The endosperm of the guar seed is mainly composed of galactomannans. The galactomannan extracted from guar seed, known as guar gum [11], is used as a binding agent and stabiliser in industries like food, chemical, pharmaceuticals, cosmetic, etc. [8,12-15].

Chloroplasts are the organelles which provide energy to the plant by the process of photosynthesis [16]. Typically, the chloroplast (Cp) genome has a circular DNA, with a quadripartite structure having two copies of inverted repeats (IRs) separated by large single copy (LSC) and small single copy (SSC) region [17,18]. Generally, the size of the chloroplast genome varies between $120 \mathrm{~kb}$ to $160 \mathrm{~kb}$ in plants, and includes 110-130 genes, primarily involved in photosynthesis, transcription, and translation [19]. It has been proposed that the size of the Cp genome is influenced by the size of the IRs [20-22]. The genes present in the IR are replicated, and hence, present in duplicated copies [23]. There are several factors which can contribute to the size variation, but mainly the expansion/contraction or loss of IR has been reported as the evident factor. Another factor contributing to the variation in genome size is gene loss and gene duplication outside the IR [24]. However, loss of IRs has been reported in some legumes (IR-lacking clade, IRLC) [25,26] and coniferous Cp genomes [27]. Partial loss of IR also has been reported in black pine, which retains $495 \mathrm{bp}$ of the IR [28]. The loss of IRs leads to a more dynamic arrangement of the Cp genome, thus undergoing gene losses and inversions in the single copy region, like in peas, as compared to the genome, which retains the IR and hence, is more stable $[29,30]$. Similarly, loss of intron has also been reported in genes like Clp protease $(c l P)$, ATP synthase $(a t p F)$, ribosomal proteins ( $r p s 12, r p l 2, r p s 16)$ and RNA polymerase (rpoC2) [31].

Legume $\mathrm{Cp}$ genomes have undergone extensive rearrangements during their evolution, leading to a couple of inversions reported in the past, like $50 \mathrm{~kb}$ inversion and $78 \mathrm{~kb}$ inversion reported in subtribe Phaseolinae [32-35]. One feature by which the legume Cp genome is characterised is the $50 \mathrm{~kb}$ inversion in the LSC region, which is observed in most legumes like Pisum sativum, Vigna radiata, Vicia faba [29], Glycine max [36,37], Cajanus cajan [38], etc. Also, during the evolution of plants, many genes have been lost from the chloroplast. Amongst these losses, some were the transfer of $\mathrm{Cp}$ genes to the nucleus. Transfer of $r p l 22$ and infA gene to the nucleus has been reported in the legume genome, and hence, their nuclear copies are targeted to the chloroplast [39-41]. Similarly, transfer of $a c c D$ gene to the nucleus has also been reported in the past [41]. Loss of intron from $r p s 12$ and $c l p P$ has also been reported in the legume genome [35,39].

Even though chloroplast genomes have a conserved organisation, some variations are still observed in the plastid genome, like loss of $a c c D$, psaI, rpl23, rps16, ycf4, and infA genes. Also, duplication of some tRNA genes, $y c f 2, r p l 23$, and $p s b A$, have been reported in the past [31,41]. Besides the loss of genes, various genes are also being reported as pseudogenes. Pseudogenes are genes that have stop codons in the protein coding sequence. The genes like ycf2 [42,43], infA, rpl23 [44], rpl33, rps16, ycf15, and $y c f 68[38]$ are the reported pseudogenes. Also, gene gain is a rare phenomenon, and not observed as frequently as gene loss in the plastid genome, as only three genes were gained in the plastome (matK, $y c f 1, y c f 2)$, whereas many have been lost or transferred to the nucleus from the plastome [30].

Since the first reports of the complete sequencing of the $C p$ genome of tobacco [45] and liverwort [46], the interest in mining useful genomic information from $\mathrm{Cp}$ genome has increased, and as a result, $1139 \mathrm{Cp}$ genome sequences of land plants are now available in NCBI Organelle Genome Resources database.

As the chloroplast genomes have a conserved gene content and organisation, and are maternally inherited [47], they serve as a valuable source for undertaking phylogenetic and evolutionary studies [48,49]. Also, due to very low levels of recombination and substitution rates, as compared to nuclear genomes, chloroplast genomes serve as useful genetic markers for phylogenetic analysis [50-52]. Chloroplast genomes are also used for DNA barcoding and breeding in agriculture [53]. A common strategy used for sequencing of the plastid genome is the use of a universal set of primers to amplify the whole $\mathrm{Cp}$ genome, followed by sequencing [54-56], or, the whole genome sequencing is done, in which total genomic DNA data is used to extract plastid genome 
sequences [57], like grapevine $\mathrm{Cp}$ genome sequence, which was obtained during the sequencing of the whole genome [58]. Next generation techniques have an advantage over labour intensive and low throughput cloning techniques, as enriched or un-enriched DNA can be used directly for sequencing [30]. The first attempt to use Next Generation Sequencing technology (454 GS 20 system) for the sequencing of Cp genome, was made by Moore et al. (2006) [59]. With the advent of Next Generation Sequencing, a large number of Cp genomes have now been sequenced [38,60-62]. Herbarium genomics has also been reported to be a promising field with respect to organelle genome sequencing [63]. Organelle genome sequencing is of great value to the branch of phylogenomics. Like genome skimming, which involves sequencing of chloroplast, mitochondrial, or rDNA, can be used to recover matrilineal genealogy [64]. Multiple platforms are available for sequencing of Cp genome, but Illumina is the most used platform for sequencing of chloroplast genomes [55,65-67]. In this study, we used purified chloroplast DNA as a template for sequencing by Illumina HiSeq 1000 platform (San Diego, CA, USA). This is the first report of the guar chloroplast genome, and hence, would help in phylogenetic analysis, DNA barcoding, and breeding in future.

\section{Materials and Methods}

\subsection{Plant Material and Chloroplast DNA Isolation}

Guar (variety RGC 936) was used in this study. Fresh leaves were harvested from the plant and kept in dark for $48 \mathrm{~h}$ prior to Cp DNA isolation. The Cp DNA isolation from the leaves was performed as per Kirti et al. (1993) [68].

\subsection{Chloroplast Genome Sequencing, Assembly, and Annotation}

The plastid libraries were prepared by Illumina Nextera DNA library preparation kit (San Diego, CA, USA). Initially, 50 ng of the plastid DNA was tagmented, cleaned, and amplified, and libraries were prepared as per manufacturer's protocol, with an average size of $500 \mathrm{bp}$. The quality check (QC) of the libraries were validated by Bioanalyzer, using DNA High sensitivity chips (Agilent Technologies, California, USA), and thereafter, the samples were run on Illumina Hiseq 1000 platform.

FastQC v0.11.5 was used to assess the per base quality of the raw reads $(50,642,415)$. A Phred score of 30 was set as the threshold for filtering reads. Average length of the reads was $96 \mathrm{bp}$. All $50,642,415$ paired-end raw reads passed the quality filter threshold of 30 Phred score. With CLC genomics (workbench 9.5.1), (CLC Bio, Arhus, Denmark) 5,882,271 (11.62\%) of these reads were mapped using the chloroplast reference genome of Glycine max (G. max), and assembled at $23 \mathrm{k}$-mer (auto). The thus obtained large contigs were reassembled again by guidance based de novo assembly with G. max Cp genome to obtain an assembly containing the largest contig, >150 kb size and N50 of 90,670 bp. A BLASTN search-based approach was used to order the contigs against the G. max Cp genome, with $>80 \%$ matches and gaps filled by filtered reads at $90 \%$ similarity over $50 \%$ length.

The annotation of the chloroplast genome was performed by Dual Organellar Genome Annotator (DOGMA) [69] and hence coding sequences (cds), rRNAs, and tRNAs were identified by using plastid genetic code and BLAST homology searches. The tRNAs were verified by online tRNAscan-SE 1.21 search serve [70]. The exact gene and exon boundaries were verified, and the start and stop codons were manually corrected.

The entire chloroplast genome sequence of Cyamopsis tetragonoloba, along with gene annotations was submitted to GenBank (accession number: MF352008).

\subsection{Genome Analysis}

Full alignments of clusterbean chloroplast genome were performed using mVISTA program [71] in Shuffle-LAGAN mode. Selected legume Cp genomes were retrieved from NCBI: Cajanus cajan 
(KU729879), G. max (NC_7942), P. vulgaris (NC_9259), Cicer arietinum (NC_11163), V. radiata (NC_13843), and Medicago truncatula (NC_003119), which were used as references.

The comparison of gene order between the chloroplast genomes of clusterbean, Arabidopsis thaliana (NC_000932), G. $\max$ (NC_7942), P. vulgaris (NC_9259), C. arietinum (NC_11163), V. radiata (NC_13843), and M. truncatula (NC_003119) was performed with MAUVE [72]. Codon usage was calculated for all exons of protein-coding genes with CodonW 1.4.4. Base composition was calculated by DNA/RNA base composition calculator [73].

\subsection{Simple Sequence Repeats Analysis}

Chloroplast microsatellites (CpSSRs) were identified in high quality sequence of clusterbean by using MISA perl script [74]. The identified cpSSRs included mononucleotide repeats $\geq 8$ bases, dinucleotides $\geq 10$ bases (five repeats), and trinucleotides and tetranucleotides $\geq 12$ bases (four and three repeats respectively), pentanucleotide $\geq 15$ bases ( 3 repeats), and hexanucleotides $\geq 18$ bases (3 repeats).

\section{Results and Discussion}

\subsection{Genome Features of Clusterbean Chloroplast Genome}

The complete chloroplast genome of clusterbean is $152,530 \mathrm{bp}$ in length. It has a typical quadripartite structure, with the Cp genome divided into LSC and SSC of 83,025 bp and 17,879 bp in size, respectively, and a pair of IRs of $25,790 \mathrm{bp}$ in size (Figure 1). The size of the Cp genome is similar to other reported legume genomes (Supplementary Table S1). The GC content for the whole genome is $35 \%$, which is in accordance with other reported legume genomes, like Glycine max [75], Cicer arietinum [33], Vigna radiata [76], and Cajanus cajan [38]. Similarly, the GC content for LSC, SSC, and IRs, is $33 \%, 29 \%$, and $42 \%$, respectively (Table 1). The high GC content for the IR regions can be attributed to the presence of four rRNAs genes ( $r r n 4.5, r r n 5, r r n 16, r r n 23)$, thus leading to sequence complexity and stabilisation of the whole genome.

The clusterbean chloroplast genome contains 114 unique genes when duplicated genes are counted only once, and includes 78 protein coding genes, 30 tRNAs, 4 rRNAs genes, and 2 pseudogenes. Individually, LSC contains 80 genes (57 protein coding genes, 22 tRNAs, and 1 pseudogene), SSC contains 13 genes (12 protein coding genes and $1 \mathrm{tRNA}$ ). The IR region consists of duplicated copies of 10 protein coding genes, 7 tRNAs, 4 rRNAs genes, and 1 pseudogene, therefore, in total, it consists of 22 genes (Table 2). The tRNA genes are distributed throughout the genome, and are encoded by 61 possible codons (excluding the stop codon). Duplicated tRNAs, trnM-CAU, and trnT-GGU, are present in the LSC region. Such tRNA duplications have been observed in the past in black pine, Actinidia, and pigeonpea $[38,77,78]$. In total, 12 intron-containing genes are present in the clusterbean Cp genome, out of which two ( $y c f 3$ and $c l p P$ ) contain two introns each (Supplementary Table S2). The trnK-UUU gene contains the largest intron (2573 bp), which also harbors the matK gene. Trans-splicing of rps12 gene is observed in the clusterbean Cp genome, as is the case with other $\mathrm{Cp}$ genomes, like Actinidia [78] and Pongamia pinnata [79]. As a result of trans-splicing, $5^{\prime}$ exon is present in the LSC region, and the $3^{\prime}$ exon is duplicated in the IR region.

In clusterbean Cp genome, the protein coding region accounts for $52.7 \%$, while the tRNA and rRNA coding regions account for $2.07 \%$ and $5.94 \%$, respectively. The remaining genome consists of the intergenic region, introns, and pseudogenes.

Codon usage was calculated for the protein coding genes present in the clusterbean $\mathrm{Cp}$ genome. A total of 78 protein coding genes, comprising a length of 80,166 nucleotides, are represented by 26,722 codons (Table 3). As reported earlier also, leucine (2831 codons, $10.5 \%$ of the total) and cysteine (318 codons, $1.19 \%$ of the total) represent the most and least abundant amino acids, respectively [80-82]. Salim and Cavalcanti (2008) [83] suggested that there exists a relationship between codon usage bias and translational efficiency. They further explain that codon usage is biased towards either abundant 
tRNAs, or those codons which binds their cognate tRNAs more strongly than others. Also, the codon usage pattern in the clusterbean $\mathrm{Cp}$ genome is observed to be biased towards a high presentation of A or $\mathrm{T}$ at third codon position (Table 1), as supported by relative synonymous codon usage (RSCU) values. The value for codons ending with $A$ and $T$ is $40.42 \%$, while codons ending with $C$ and $G$ is $12.61 \%$. This bias towards the high presentation of $\mathrm{A}$ or $\mathrm{T}$ is also observed in other $\mathrm{Cp}$ genomes $[82,84]$. It has also been reported in the past that organellar proteins are encoded mainly by codons ending with A or U [85].

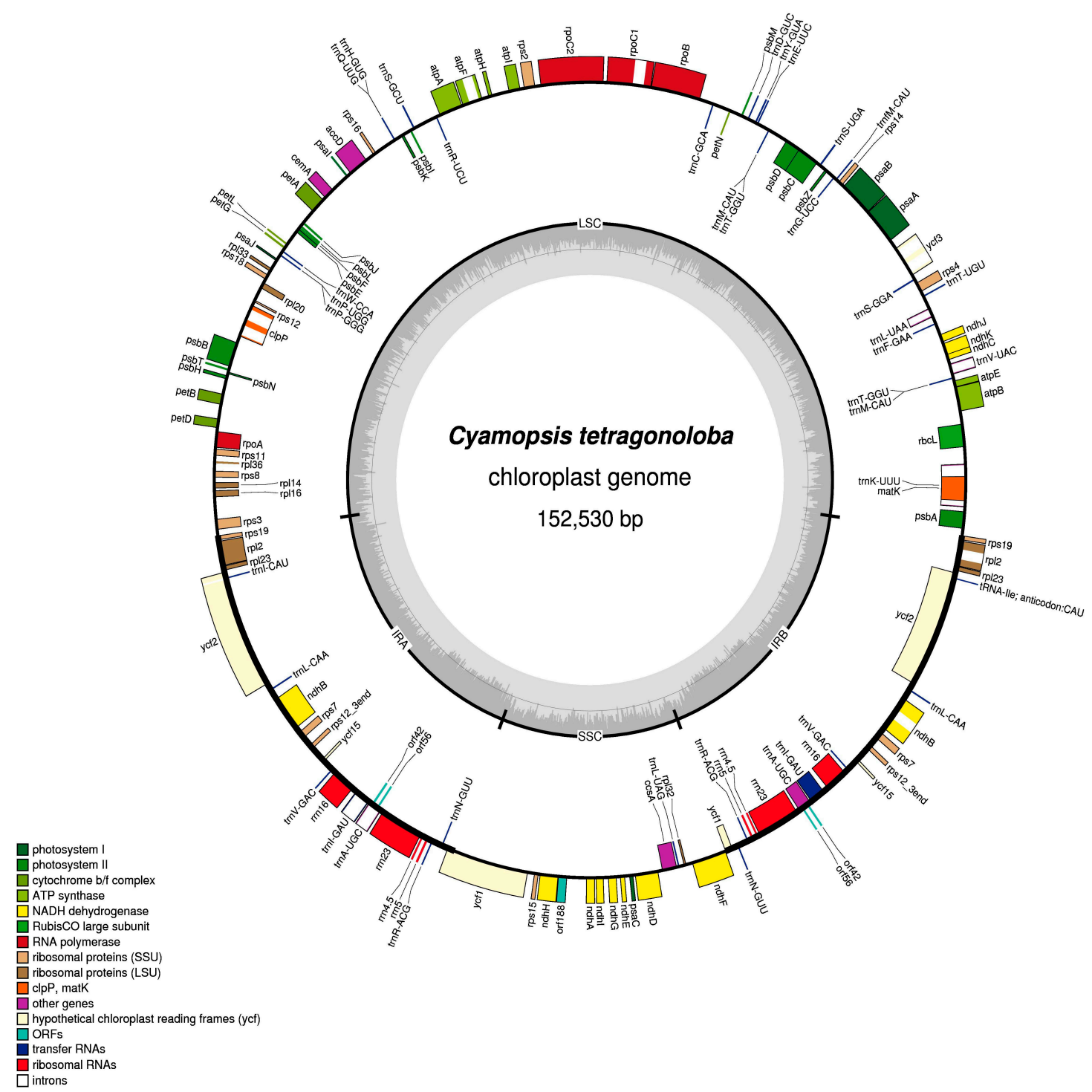

Figure 1. Map of Cyamopsis tetragonoloba plastid genome. Genes shown on the outside of the map are transcribed clockwise, while the genes that are shown on the inside are transcribed counterclockwise. The innermost darker gray corresponds to GC content, whereas the lighter gray corresponds to AT content. Different genes are colour coded. IR: inverted repeat; LSC: large single copy region; SSC: small single copy region.

During the course of evolution, there have been many cases of intron and full gene losses among the angiosperms. Homologous recombination between intron-less cDNA and the original intron containing copy of DNA has been proposed as one of the mechanisms for the loss of introns. Loss of intron of atpF gene in Malpighiales was explained by the above mechanism [86,87]. Likewise, it has been reported that a clade known as IR-lacking clade (IRLC), which includes Cicer arietinum, 
Medicago truncatula, Trifolium subterraneum, Pisum sativum, and Lathyrus sativus, has lost clpP introns. Loss of intron from rpl2 gene was also reported from various lineages of flowering plants [24]. Nevertheless, introns play an important role in gene expression, as the presence of an intron enhances the gene's transcription. Also, introns present within the gene can be used as flanking sequences for the purpose of genetic engineering, thus providing efficient processing of foreign transcripts [53].

Table 1. Features of the chloroplast genome of Cyamopsis tetragonoloba. T: Thymine; U: Uridine; C; Cytosine; A: Adenine; G: Guanosine; IRa: Inverted Repeat a; IRb: Inverted Repeat b.

\begin{tabular}{ccccccc}
\hline Features & T/U\% & $\mathbf{C} \%$ & $\mathbf{A} \%$ & $\mathbf{G} \%$ & Length (bp) & AT\% \\
\hline Genome & 32 & 17 & 32 & 18 & 152,530 & 65 \\
LSC & 34 & 16 & 34 & 17 & 83,025 & 67 \\
SSC & 35 & 14 & 36 & 15 & 17,879 & 71 \\
IRa/IRb & 29 & 20 & 29 & 22 & 25,790 & 58 \\
Prt.Coding genes & 32 & 17 & 31 & 19 & 80,166 & 64 \\
tRNA & 26 & 23 & 22 & 29 & 3172 & 48 \\
rRNA & 19 & 23 & 26 & 31 & 9070 & 45 \\
First position & 24.1 & 18.4 & 31.5 & 25.8 & 26,722 & 55.6 \\
Second position & 33.2 & 19.9 & 29.6 & 17.1 & 26,722 & 62.8 \\
Third position & 39.1 & 12.9 & 30.0 & 14.7 & 26,722 & 69.1 \\
\hline
\end{tabular}

Table 2. List of genes present in the Cp genome of clusterbean.

\begin{tabular}{|c|c|}
\hline Category & Gene Name \\
\hline Photosystem I & $p s a A, B, C, I, J, Y c f 3^{a}$ \\
\hline Photosystem II & $p s b A, B, C, D, E, F, H, I, J, K, L, M, N, T, Z / l h b A$ \\
\hline Cytochrome b6/f & pet $A, B, D, G, L, N$ \\
\hline ATP Synthase & atp $A, B, E, F^{b}, H, I$ \\
\hline Rubisco & $r b c L$ \\
\hline NADH Oxidoreductase & $n d h A, B{ }^{b, c}, C, D, E, F, G, H, I, J, K$ \\
\hline Large subunit ribosomal proteins & $r p l 2^{b, c}, 14,16,20,23^{c}, 32,33,36$ \\
\hline Small subunit ribosomal proteins & $\operatorname{rps} 2,3,4,7^{c}, 8,11,12^{c, d}, 14,15,16^{e}, 18,19$ \\
\hline RNAP & $\operatorname{rpo} A, r p o B, C 1^{b}, C 2$ \\
\hline Other Proteins & $\operatorname{accD}, \operatorname{ccs} A, \operatorname{mat} K, \operatorname{cem} A, \operatorname{clp} P^{a}$ \\
\hline Proteins of unknown Function & $y c f 1^{c}, y c f 2^{b, c}, y c f 15^{c, e}, \operatorname{orf} 42^{c}$, orf $56^{c}$, orf 188 \\
\hline Ribosomal RNAs & $\operatorname{rrn} 23^{c}, 16^{c}, 5^{c}, 4.5^{c}$ \\
\hline Transfer RNAs & $\begin{array}{c}\operatorname{trnH}(G U G), K(U U U)^{b}, M(C A U), T(G G U), V(U A C)^{b}, F(G A A), \\
L(U A A)^{b}, T(U G U), S(G G A), f M(C A U), \\
G(U C C), S(U G A), E(U U C), Y(G U A), D(G U C), C(G C A), R(U C U), \\
S(G C U), Q(U U G), W(C C A), P(U G G), P(G G G), I(C A U)^{c}, L(C A A)^{c}, \\
V(G A C)^{c}, I(G A U)^{b, c}, A(U G C)^{b, c}, R(A C G)^{c}, N(G U U)^{c}, L(U A G)\end{array}$ \\
\hline
\end{tabular}

${ }^{a}$ Gene containing two introns; ${ }^{b}$ Gene containing a single intron; ${ }^{c}$ Two gene copies in the IRs; ${ }^{d}$ Gene divided into two independent transcription units; $^{e}$ Pseudogenes. RNAP: RNA Polymerase.

Table 3. Codon Usage for Cyamopsis tetragonoloba.

\begin{tabular}{ccccc}
\hline Amino Acid & Codon & Count & RSCU & tRNA \\
\hline Ala & GCG & 127 & 0.09 & trnA-UGC \\
Ala & GCA & 396 & 0.29 & \\
Ala & GCT & 629 & 0.47 & \\
Ala & GCC & 193 & 0.14 & \\
Cys & TGT & 231 & 0.73 & trnC-GCA \\
Cys & TGC & 87 & 0.27 & \\
Asp & GAT & 836 & 0.80 & trnD-GUC \\
Asp & GAC & 211 & 0.20 & \\
Glu & GAG & 322 & 0.23 & trnE-UUC \\
Glu & GAA & 1051 & 0.77 & \\
Phe & TTT & 1106 & 0.68 & trnF-GAA \\
Phe & TTC & 509 & 0.32 & \\
\hline
\end{tabular}


Table 3. Cont.

\begin{tabular}{|c|c|c|c|c|}
\hline Amino Acid & Codon & Count & RSCU & tRNA \\
\hline Gly & GGG & 284 & 0.16 & trnG-UCC \\
\hline Gly & GGA & 698 & 0.40 & \\
\hline Gly & GGT & 588 & 0.34 & \\
\hline Gly & GGC & 162 & 0.09 & \\
\hline His & CAT & 511 & 0.79 & $\operatorname{trnH}-\mathrm{GUG}$ \\
\hline His & CAC & 136 & 0.21 & \\
\hline Ile & ATA & 838 & 0.35 & trnI-GAU \\
\hline Ile & ATT & 1188 & 0.49 & trnI-CAU \\
\hline Ile & ATC & 401 & 0.17 & \\
\hline Lys & AAG & 335 & 0.22 & trnK-UUU \\
\hline Lys & AAA & 1185 & 0.78 & \\
\hline Leu & TTG & 561 & 0.20 & trnL-UAA \\
\hline Leu & TTA & 944 & 0.33 & $\operatorname{trnL}-\mathrm{CAA}$ \\
\hline Leu & CTG & 168 & 0.06 & trnL-UAG \\
\hline Leu & CTA & 389 & 0.14 & \\
\hline Leu & CTT & 590 & 0.21 & \\
\hline Leu & СТC & 179 & 0.06 & \\
\hline Met & ATG & 607 & 1.00 & $\operatorname{trnM}-\mathrm{CAU}$ \\
\hline Asn & AAT & 1051 & 0.78 & $\operatorname{trnN}$-GUU \\
\hline Asn & AAC & 291 & 0.22 & \\
\hline Pro & CCG & 128 & 0.12 & trnP-GGG \\
\hline Pro & CCA & 339 & 0.31 & trnP-UGG \\
\hline Pro & $\mathrm{CCT}$ & 406 & 0.37 & \\
\hline Pro & $\mathrm{CCC}$ & 211 & 0.19 & \\
\hline Gln & CAG & 204 & 0.21 & trnQ-UUG \\
\hline Gln & CAA & 764 & 0.79 & \\
\hline Arg & AGG & 159 & 0.10 & $\operatorname{trnR}-\mathrm{UCU}$ \\
\hline Arg & AGA & 494 & 0.32 & trnR-ACG \\
\hline Arg & CGG & 105 & 0.07 & \\
\hline Arg & CGA & 364 & 0.23 & \\
\hline Arg & CGT & 347 & 0.22 & \\
\hline Arg & CGC & 91 & 0.06 & \\
\hline Ser & AGT & 404 & 0.20 & trnS-UGA \\
\hline Ser & AGC & 121 & 0.06 & trnS-GGA \\
\hline Ser & TCG & 181 & 0.09 & trnS-GCU \\
\hline Ser & TCA & 442 & 0.21 & \\
\hline Ser & TCT & 604 & 0.29 & \\
\hline Ser & TCC & 306 & 0.15 & \\
\hline Thr & ACG & 136 & 0.10 & $\operatorname{trnT-UGU}$ \\
\hline Thr & ACA & 424 & 0.31 & trnT-GGU \\
\hline Thr & ACT & 577 & 0.43 & \\
\hline Thr & ACC & 219 & 0.16 & \\
\hline Val & GTG & 175 & 0.12 & trnV-UAC \\
\hline Val & GTA & 540 & 0.38 & trnV-GAC \\
\hline Val & GTT & 540 & 0.38 & \\
\hline Val & GTC & 162 & 0.11 & \\
\hline $\operatorname{Trp}$ & TGG & 448 & 1.00 & $\operatorname{trnW}-\mathrm{CCA}$ \\
\hline Tyr & TAT & 852 & 0.83 & trnY-GUA \\
\hline Tyr & TAC & 170 & 0.17 & \\
\hline Ter & TGA & 3 & 0.60 & \\
\hline Ter & TAG & 2 & 0.40 & \\
\hline Ter & TAA & 0 & 0.00 & \\
\hline
\end{tabular}

RSCU: relative synonymous codon usage.

As is the case with intron loss, various gene losses have also been reported in angiosperms. Likewise, $r p l 22$ and infA genes are observed to be missing from clusterbean chloroplast genome. The independent transfer of rpl22 gene to the nucleus has been reported in Fabaceae [40] and Fagaceae [88]. Similarly, transfer of infA gene to the nucleus has been documented in rosids, and was supported by the finding of expressed copies of the gene with stretches of chloroplast transit peptide in the nucleus [89]. The transfer of $r p l 32$ gene in Salicaceae [90,91] and accD gene in Trifolium [41] have also been well documented. The $a c c D$ gene has been reported to be lost at least seven times in the course of evolution of angiosperms. In some plastid genomes, like Medicago and Populus, the phenomenon of nuclear substitution has been reported as a cause for loss of rps16 gene from the 
plastome, as the nuclear encoded, mitochondrial copy of the gene is targeted to the plastid also [92]. But in the plastid genome of clusterbean, rps16 gene has been found to be present as a pseudogene. Similarly, it is present as a pseudogene in Cp genome of pigeonpea [38], while its non-functional copy is present in V.radiata [76]. Loss of splicing activity might be the reason for it to be present as a pseudogene [93]. Also, ycf15 is observed to be present as a pseudogene in clusterbean Cp genome. It has also been reported, in the past, to be present as a pseudogene in the Cp genome of pigeonpea [38], Phaseolus vulgaris, and Vigna radiata [33,76], as it contains premature stop codons within the coding sequence. It can be concluded from the above reports that increased rate of hypermutation has made the legumes more prone to rearrangements, and thus, more number of genes are lost or relocated to the nucleus in legumes [41,94].

\subsection{Gene Order}

Each of the sequenced legume $\mathrm{Cp}$ genomes possesses a unique structure. To deduce the structural homology, we compared the $\mathrm{Cp}$ genome of clusterbean with the sequenced legume genomes using MAUVE (Figure 2), taking Arabidopsis Cp genome as a reference. On comparison with Arabidopsis, it was found that the clusterbean and all the legume Cp genomes possesses a $50 \mathrm{~kb}$ inversion in LSC, spanning the region between the $r b c l$ and rps16 genes of the chloroplast.

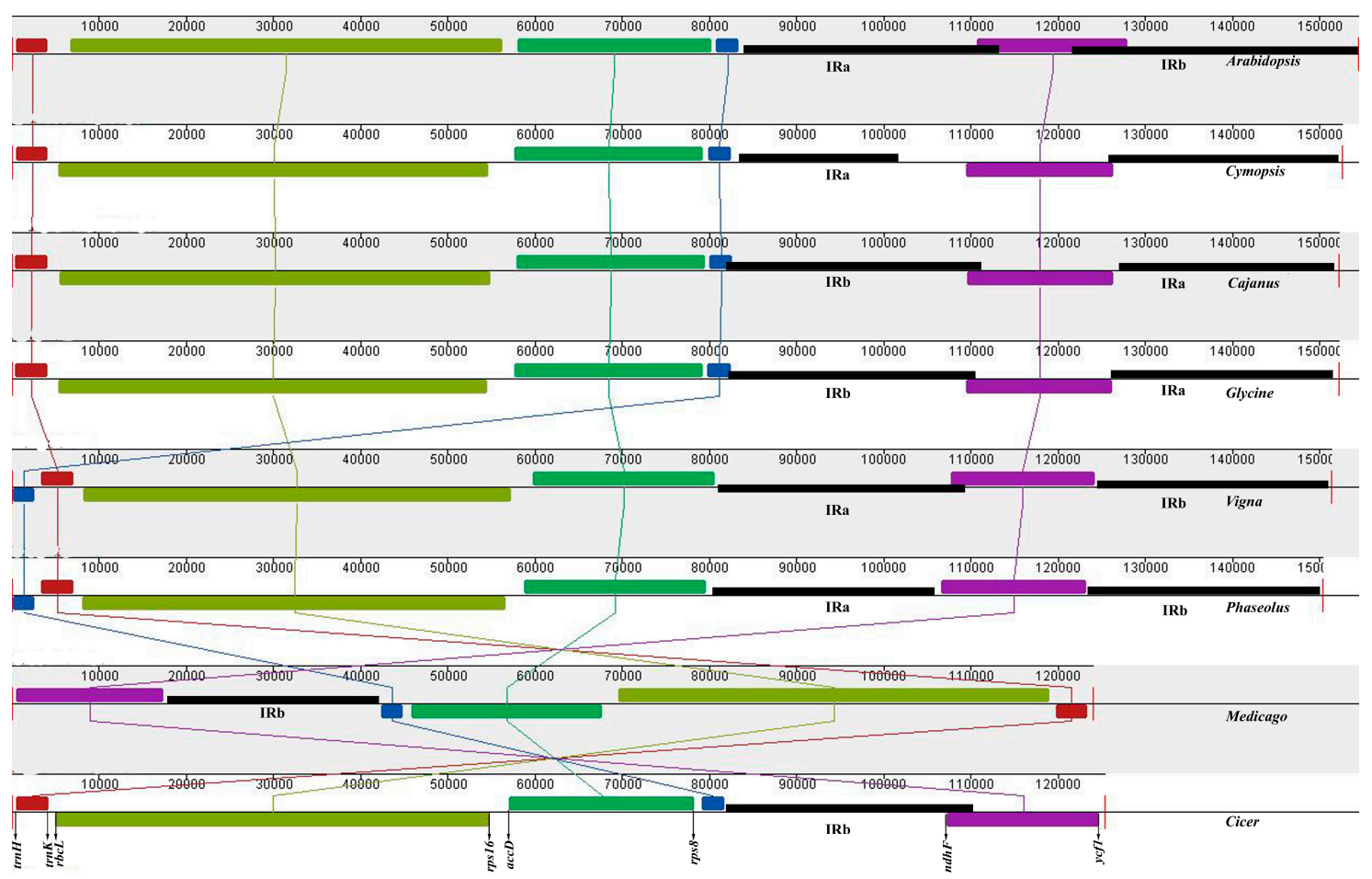

Figure 2. Gene order comparison of legume plastid genomes, with Arabidopsis Cp genome as reference, using MAUVE software. The boxes above the line represent the gene sequence in clockwise direction, and the boxes below the line represent gene sequences in the opposite orientation. The gene names at the bottom indicate the genes located at the boundaries of the boxes in $\mathrm{Cp}$ genome of pigeonpea.

The clusterbean $\mathrm{Cp}$ genome also possesses an additional inversion within the LSC and the IR region, occurring as a result of flip flop intramolecular recombination [95]. This inversion is also observed for G. max and pigeonpea $\mathrm{Cp}$ genome. The $\mathrm{Cp}$ genomes of Cicer arietinum and Medicago truncatula generally share the same gene order with clusterbean, except for the loss of $\mathrm{IRb}$ region in the former. This loss of IR region has been reported earlier too [96], and such legume tribes, lacking one IR region, form a new clade known as Inverted Repeat-lacking clade (IRLC) $[97,98]$. 
An inversion unique to subtribe phaseolinae, occurring as a result of expansion and subsequent contraction of IRs [99], is present in the Cp genome of V. radiata and P. vulgaris, but absent from other plastid genomes. This suggests that legume $\mathrm{Cp}$ genomes have undergone considerable rearrangements and diversification, and thus, provide a valuable resource for phylogenetic analysis.

\subsection{Plastid Genome Sequence Comparison}

The availability of various legume plastid genomes provides the opportunity for comparison of $\mathrm{Cp}$ genomes. Hence, the sequence identity of the legume Cp genomes was plotted with the help of mVISTA (Figure 3), using annotations of clusterbean as reference. On alignment, it was found that the overall chloroplast genomes were conservative with some divergent regions. Similar to other plant species, coding regions were found to be more conservative than the non-coding regions. The most conserved region was the IR region, probably due to the presence of conserved rRNA genes and the phenomenon of copy correction [100]. The coding regions like $\operatorname{clp} P, \operatorname{accD}, \operatorname{pet} A, \operatorname{pet} D$, and $\operatorname{cem} A$ show high a degree of divergence, while the intergenic region between the genes $r p o B-p s b D, n d h C-a t p B$, $p s b E-p s b B$, petD-rps3, trnK-UUU-rbcl, and $n d h J-y c f 3$, also show a high degree of divergence.

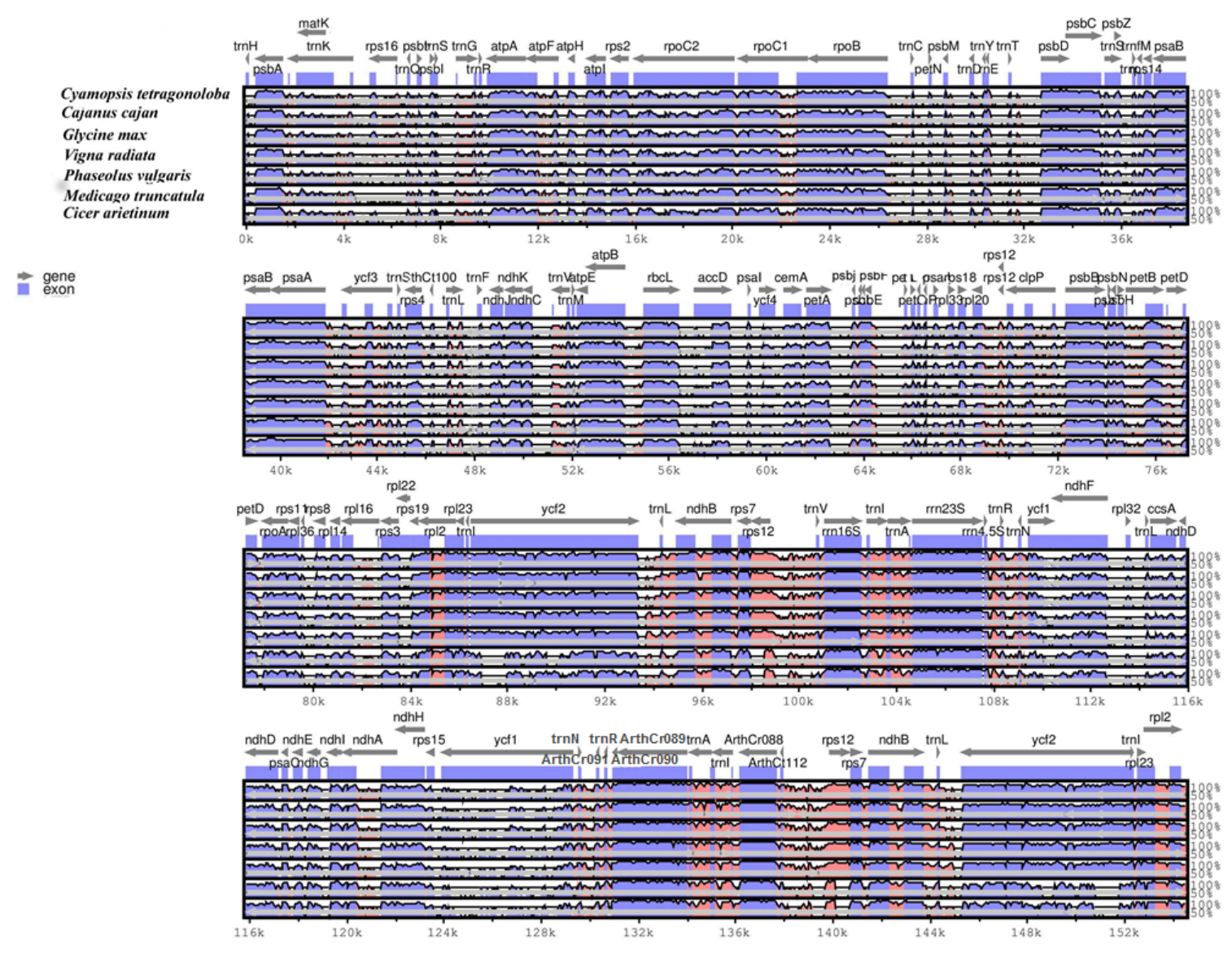

Figure 3. Sequence alignment of legume plastid genomes, with C. tetragonoloba $\mathrm{Cp}$ genome set as a reference using mVISTA. Position and transcriptional direction of each gene is indicated by gray arrows. Intergenic and genic regions are indicated by red and blue areas, respectively. Sequence identity between the Cp genomes is shown on y-axis as a percentage between $50 \%$ to $100 \%$.

\subsection{Comparison of Inverted Repeat Boundaries of Clusterbean with Other Closely Related Plastid Genomes}

The IR regions are known to promote the stability of the rest of the genome by intramolecular recombination between the two copies of inverted repeats, and thus, limiting the recombination between the two single copy regions [97,101]. The contraction and expansion of IRs leads to the 
size variation of the plastid genomes among the angiosperms. The comparison of the boundaries of clusterbean $\mathrm{Cp}$ genome with other plastid genomes is presented in Figure 4. The IR region of clusterbean contains 22 completely duplicated genes. At the IR/LSC junction, rps19 gene is included in the IR region, and hence, is completely duplicated. On the other hand, at the IR/SSC junction, $485 \mathrm{bp}$ of $y c f 1$ gene is included in the IR. As a result, a partial ycf1 gene is included at the IRa/SSC junction, while the complete $y c f 1$ gene is included in the IR at the SSC/IRb junction. In comparison to other genomes, these boundaries fluctuate, like in G.max Cp genome, where $68 \mathrm{bp}$ of $r p s 19$ gene is included in the IR. Meanwhile, complete duplication of the rps19 gene is seen in Vigna radiata and Phaseolus vulgaris, in contrast with the absence of rps19 in the IR regions of pigeonpea. On the other hand, ycf1 gene is included in the IRs of all the compared legumes, but the size varies among them. On comparison with other closely related legumes, the IR region of clusterbean (25,790 bp) was found to be smaller than that of Vigna radiata (26,474 bp), but larger than the IR region of Cajanus cajan $(25,398 \mathrm{bp})$.

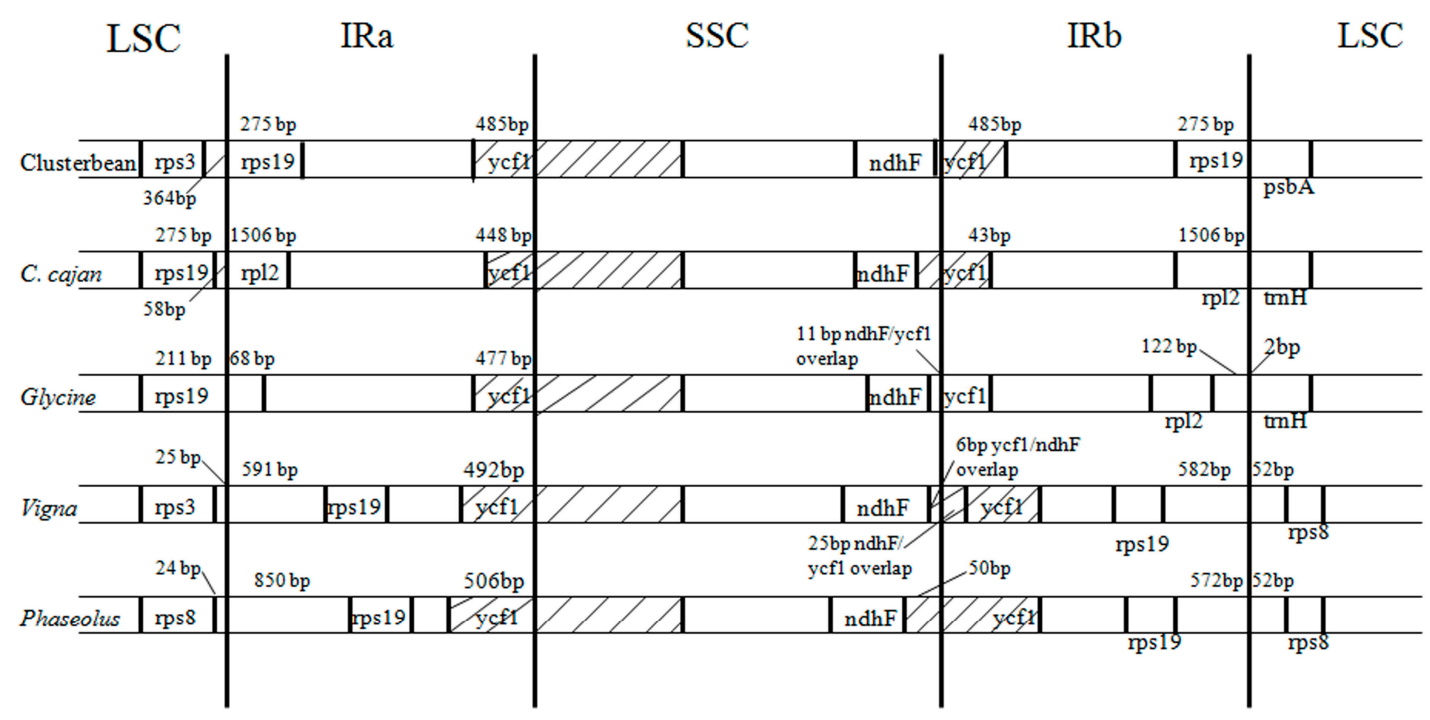

Figure 4. Comparison of the border positions of LSC, SSC and IR regions among the legume genomes. Genes are denoted by boxes, and the gaps between the genes and the boundaries are indicated by number of bases, unless the gene coincides with the boundary. Extensions of the genes are also indicated above the boxes.

\subsection{Simple Sequence Repeats Analysis}

A group of tandem repeat sequences consisting of 1-6 nucleotide repeat units are known as simple sequence repeats (SSRs), or microsatellites [102]. CpSSRs are known to be relatively abundant, and demonstrate high reproducibility and polymorphism. Thus, these are frequently used in species identification and genetic analysis. Chloroplast SSRs were extracted using MISA perl script, and a total of 220 SSRs were detected in the clusterbean Cp genome (Supplementary Table S3). The numbers of SSR loci found are similar to that reported in Vigna radiata, but less than that reported in pigeonpea [88,103]. Among 220 SSRs reported, 67.27\% (148 SSRs) are present in LSC region, 11.81\% (26 SSRs) are present in IR region, and $20.9 \%$ (46 SSRs) are present in the SSC region (Figure 5). The findings were similar to that reported in artichoke [104] and Datura stramonium Cp genome [80]. Further, the SSRs were distributed among the coding, non-coding, and intergenic regions. Additionally, it was found that 33\% (72) of the SSRs were present in the coding region, 4\% (10 SSRs) in the intronic region and $63 \%$ (138) were present in the intergenic region (Figure 6). Also on comparison between coding and non-coding region, a higher number of SSRs were found to be present in the non-coding region than the coding region, making the results consistent with those observed for G. max [105] and Datura stramonium [80]. 
On the basis of the arrangement of nucleotides in the repeat motif, $78 \%$ of the SSRs were found to be perfect repeats, while $15 \%, 6 \%$, and $1 \%$ were found to be compound interrupted, imperfect, and compound repeats, respectively. The microsatellites were further analysed on the basis of repeat types. The most abundant repeat type was mononucleotide, and the least abundant was pentanucleotide, with no hexanucleotide motifs detected (Figure 7). These repeat types were distributed among the coding and non-coding region (Figure 8). On analysis of these repeat types, it was found that mono, $\mathrm{di}$, and trinucleotide repeats were mainly composed of A or T nucleotides. Wheeler et al. (2014) [106] also reported that the majority of mononucleotides are $\mathrm{A} / \mathrm{T}$ rich. This bias in base composition is also consistent with overall AT richness in the clusterbean plastid genome. Such A/T rich repeats were also reported in Camellia species, Sesame indicum, Glycine species and Sesamum indicum [105,107-109].

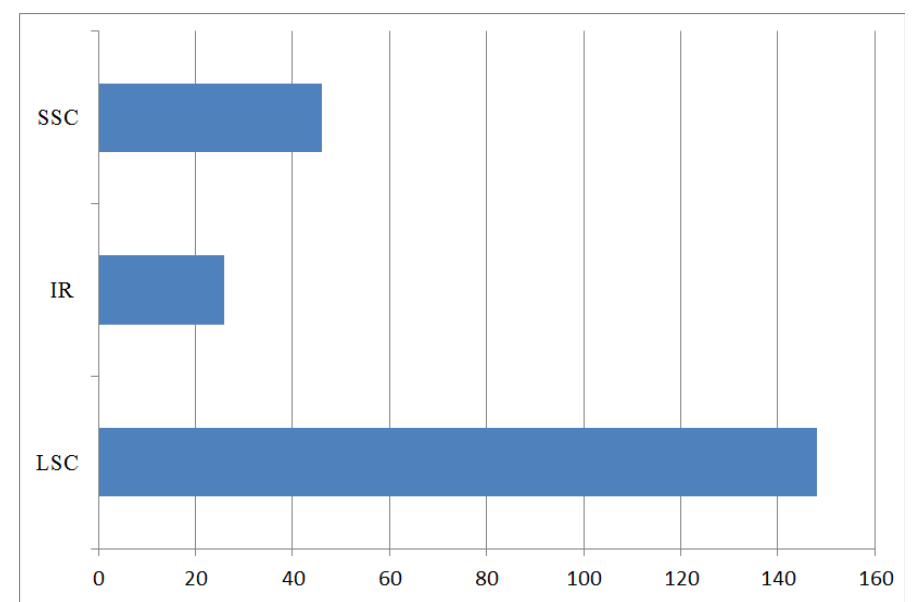

Figure 5. Simple sequence repeats (SSRs) distribution in three different regions: LSC, SSC and IR region. $\mathrm{X}$-axis represents the number of SSRs.

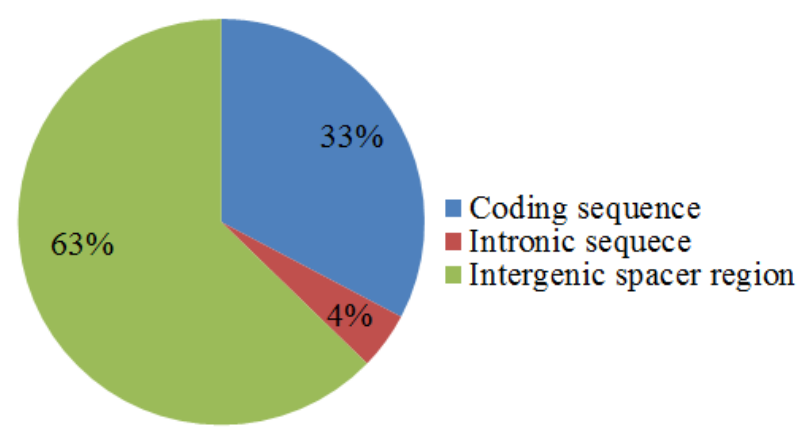

Figure 6. Repeat distribution among three different regions: coding sequences, intronic sequences, and intergenic spacer regions.

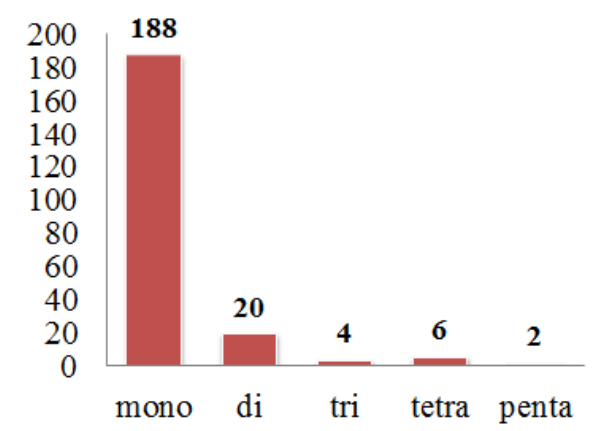

Figure 7. SSR distribution on the basis of repeat type. Y-axis represents the number of SSRs. 


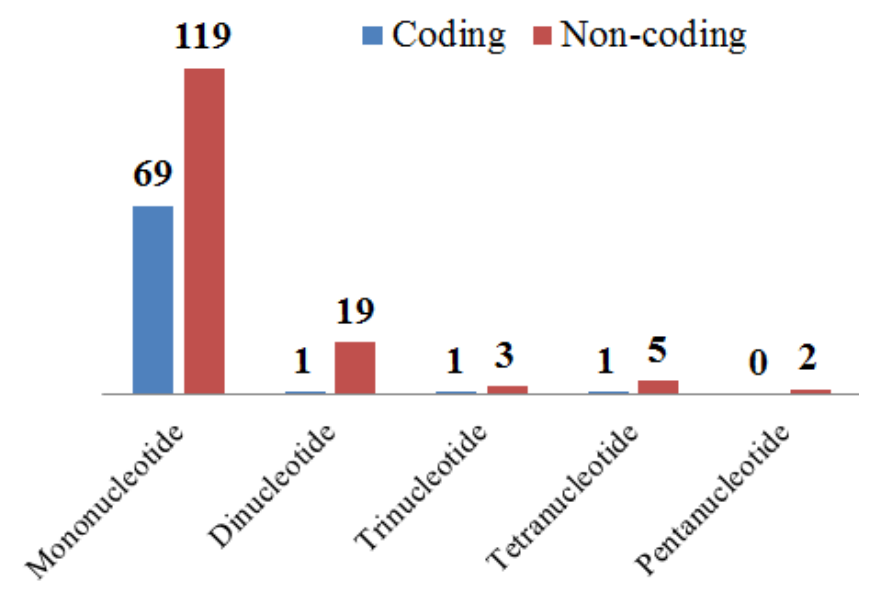

Figure 8. SSR type distribution between coding and non-coding regions. Y-axis represents the number of SSRs.

Among the coding sequences, maximum numbers of repeats were detected in the ycf1 gene region. In recent studies, $y c f 1$ gene is considered as the most variable locus $[80,110]$. The finding is consistent with others reported from Glycine species, V. radiata, Camellia species, Cynaracardunculus $[76,104,105,108]$.

\section{Conclusions}

The clusterbean plastid genome was sequenced on an Illumina Hi-Seq 1000 platform, and the assembly was done using CLC Genomics Workbench 9.5.1. The genome is $152,530 \mathrm{bp}$ in length, with a typical quadripartite structure, and consists of 114 unique genes, similar to other reported legume plastid genomes. This is the first study reporting the draft chloroplast genome sequence of clusterbean. The plastid genome of clusterbean, on comparison with other legumes, shows similar organisation, except for the IR expansion, where rps19 is included in the IRs, and hence, completely duplicated. It also consists of two pseudogenes, namely rps16 and ycf15. Gene loss is also observed, as the genes rpl22 and infA are absent from the plastid genome. On doing SSR analysis, 220 SSR loci were found, with most SSRs present in the intergenic region. This study would be helpful in evolutionary and molecular studies.

Supplementary Materials: The following are available online at www.mdpi.com/2073-4425/8/9/212/s1. Table S1: Size comparison among six Cp genomes completely sequenced in legumes; Table S2: List of genes with introns in Cp genome of Cyamopsis tetragonoloba; Table S3: SSRs found in Cyamopsis tetragonoloba.

Acknowledgments: We acknowledge the financial support from ICAR-CRP on Genomics platform (NBFGR, Lucknow, India). We also acknowledge the logistic support provided by PD, ICAR-NRCPB, New Delhi.

Author Contributions: T.K. carried out the experiments, prepared the genomic library for Illumina sequencing run and wrote the manuscript. P.K.C. and H.C.R. performed chloroplast genome assembly and bioinformatics analysis. S.S. carried out the SSR markers discovery and validation. T.K., P.K.C., S.S., and A.T. were involved in the result interpretation, analysis, and finalisation of the manuscript. S.V.A.M., A.U.S., T.R.S. and N.K.S. contributed in data analysis, genome annotation and manuscript finalisation. P.K. provided the seeds and contributed to manuscript. K.G. conceived the study, designed the experiments, and coordinated the work. All the authors have read and approved the final manuscript.

Conflicts of Interest: The authors declare no conflict of interest. 


\section{Abbreviations}

$\begin{array}{ll}\text { Cp } & \text { chloroplast } \\ \text { LSC } & \text { large single-copy region } \\ \text { SSC } & \text { small single-copy region } \\ \text { IR } & \text { inverted repeat } \\ \text { DNA } & \text { deoxyribonucleic acid } \\ \text { bp } & \text { base pair(s) } \\ \text { GC } & \text { guanine-cytosine } \\ \text { AT } & \text { adenosine-thymine } \\ \text { kb } & \text { kilobase(s) } \\ \text { RNA } & \text { ribonucleic acid } \\ \text { rRNA } & \text { ribosomal RNA } \\ \text { SSR } & \text { simple sequence repeat(s) } \\ \text { tRNA } & \text { transfer RNA }\end{array}$

\section{References}

1. Ashraf, M.Y.; Akhtar, K.; Sarwar, G.; Ashraf, M. Role of the rooting system in salt tolerance potential of different Guar accessions. Agron. Sustain. Dev. 2005, 25, 243-249. [CrossRef]

2. Francois, L.E.; Donovan, T.J.; Maas, E.V. Salinity effects on emergence, vegetative growth and seed yield of Guar. Agron. J. 1990, 82, 587-592. [CrossRef]

3. Gresta, F.; De Luca, A.I.; Strano, A.; Falcone, G.; Santonoceto, C.; Anastasi, U.; Gulisano, G. Economic and environmental sustainability analysis of guar (Cyamopsis tetragonoloba L.) farming process in a mediterranean area: Two case studies. Ital. J. Agron. 2014, 9, 20-24. [CrossRef]

4. Undersander, D.J.; Putnam, D.H.; Kaminski, A.R.; Kelling, K.A.; Doll, J.D.; Oplinger, E.S.; Gunsolus, J.L. Guar. In Alternative Field Crops Manual; University of Wisconsin-Extension: Madison, WI, USA, 1991.

5. Tucker, B.; Foraker, R. Cotton and grain sorghum yields following Guar and Cowpeas compared to continuous cropping. AGRIS 1975, 728, 24-27.

6. Tripp, L.D.; Lovelace, D.A.; Boring, E.P., III. Keys to profitable Guar production; Texas Agricultural Experimental Station Bulletin: College Station, TX, USA, 2011; pp. 7-11.

7. Elsheikh, E.A.E.; Ibrahim, K.A. The effect of Bradyrhizobium inoculation on yield and seed quality of guar (Cyamopsis tetragonoloba L.). Food Chem. 1999, 65, 183-187. [CrossRef]

8. Kalyani, D.L. Performance of Cluster Bean Genotypes under Varied Time of Sowing. Legum. Res. Int. J. 2012, 35, 154-158.

9. Aykroyd, U.R. Indian Council of Medical Research, Special Report; Vegetable, National Book Trust India: New Delhi, India, 1963; Volume 42, pp. 188-191.

10. Jackson, K.J.; Doughton, J.A. Guar: A potential industrial crop for dry tropics of Australia. J. Aust. Inst. Agric. Sci. 1982, 42, 17-31.

11. Miyazawa, T.; Funazukuri, T. Noncatalytic hydrolysis of guar gum under hydrothermal conditions. Carbohydr. Res. 2006, 341, 870-877. [CrossRef] [PubMed]

12. Lubbe, A.; Verpoorte, R. Cultivation of medicinal and aromatic plants for specialty industrial materials. Ind. Crops Prod. 2011, 34, 785-801. [CrossRef]

13. Barak, S.; Mudgil, D. Locust bean gum: Processing, properties and food applications-A review. Int. J. Biol. Macromol. 2014, 66, 74-80. [CrossRef] [PubMed]

14. Sainy, M.I.; Paroda, R.S. Guar cultivation in Haryana, India. Department of Plant Breeding. Chaudhary Charan Singh Agric. J. 1984, 104, 199-203.

15. Vaughna, S.F.; Berhowa, M.A.; Winkler-Mosera, J.; Lee, E. Formulation of a biodegradable, odor-reducing cat litter from solvent-extracted corn dried distillers grains. Ind. Crops Prod. 2011, 34, 999-1002. [CrossRef]

16. Douglas, S.E. Plastid evolution: Origins, diversity, trends. Curr. Opin. Genet. Dev. 1990, 8, 655-661. [CrossRef]

17. Raubeson, L.A.; Jansen, R.K. Chloroplast genomes of plants. In Plant Diversity and Evolution: Genotypic and Phenotypic Variation in Higher Plants; Henry, R.J., Ed.; CABI Press: Cambridge, MA, USA, 2005; pp. $45-68$. 
18. Wicke, S.; Schneeweiss, G.M.; dePamphilis, C.W.; Müller, K.F.; Quandt, D. The evolution of the plastid chromosome in land plants: Gene content, gene order, gene function. Plant Mol. Biol. 2011, 76, 273-297. [CrossRef] [PubMed]

19. Sugiura, M. The chloroplast genome. Plant Mol. Biol. 1992, 19, 149-168. [CrossRef] [PubMed]

20. Chang, C.C.; Lin, H.C.; Lin, I.P.; Chow, T.Y.; Chen, H.H.; Chen, W.H.; Cheng, C.H.; Lin, C.Y.; Liu, S.M.; Chang, C.C.; et al. The chloroplast genome of Phalaenopsis aphrodite (Orchidaceae): Comparative analysis of evolutionary rate with that of grasses and its phylogenetic implications. Mol. Biol. Evol. 2006, 23, 279-291. [CrossRef] [PubMed]

21. Wang, R.J.; Cheng, C.L.; Chang, C.C.; Wu, C.L.; Su, T.M.; Chaw, S.M. Dynamics and evolution of the inverted repeat-large single copy junctions in the chloroplast genomes of monocots. BMC Evol. Biol. 2008, 8, 36. [CrossRef] [PubMed]

22. Bock, R. (Ed.) Structure, function, and inheritance of plastid genomes. In Cell and Molecular Biology of Plastids; Springer: Berlin/Heidelberg, Germany, 2007; pp. 29-63.

23. Palmer, J.D.; Thompson, W.F. Rearrangements in the chloroplast genomes of mung bean and pea. Proc. Natl. Acad. Sci. USA 1981, 78, 5533-5537. [CrossRef] [PubMed]

24. Jansen, R.K.; Ruhlman, T.A. Plastid genomes of seed plants. In Genomics of Chloroplasts and Mitochondria: Advances in Photosynthesis and Respiration; Bock, R., Knoop, V., Eds.; Springer: Dordrecht, The Netherlands, 2012; Volume 35, pp. 103-126.

25. Wojciechowski, M.F.; Sanderson, M.J.; Steele, K.P.; Liston, A. Molecular phylogeny of the “Temperate Herbaceous Tribes" of papilionoid legumes: A supertree approach. Adv. Legum. Syst. 2000, 9, 277-298.

26. Strauss, S.H.; Palmer, J.D.; Howe, G.T.; Doerksen, A.H. Chloroplast genomes of two conifers lack a large inverted repeat and are extensively rearranged. Proc. Natl. Acad. Sci. USA 1988, 85, 3898-3902. [CrossRef] [PubMed]

27. Tsudzuki, J.; Nakashima, K.; Tsudzuki, T.; Hiratsuka, J.; Shibata, M.; Wakasugi, T.; Sugiura, M. Chloroplast DNA of black pine retains a residual inverted repeat lacking rRNA genes: Nucleotide sequences of $\operatorname{trn} Q$, trnK, $p s b A, \operatorname{trnI}$ and trnH and the absence of rps16. Mol. Gen. Genet. 1992, 232, 206-214. [PubMed]

28. Palmer, J.D.; Thompson, W.F. Chloroplast DNA rearrangements are more frequent when a large inverted repeat sequence is lost. Cell 1982, 29, 537-550. [CrossRef]

29. Jansen, R.K.; Cai, Z.; Raubeson, L.A.; Daniell, H.; dePamphilis, C.W.; Leebens-Mack, J.; Muller, K.F.; Guisinger-Bellian, M.; Haberle, R.C.; Hansen, A.K.; et al. Analysis of 81 genes from 64 plastid genomes resolves relationships in angiosperms and identifies genome-scale evolutionary patterns. Proc. Natl. Acad. Sci. USA 2007, 104, 19369-19374. [CrossRef] [PubMed]

30. Wicke, S.; Schneeweiss, G.M. Next-generation organellar genomics: Potentials and pitfalls of high-throughput technologies for molecular evolutionary studies and plant systematics. In Next-Generation Sequencing in Plant Systematics; Hörandl, E., Appelhans, M., Eds.; International Association for Plant Taxonomy (IAPT): Bratislava, Slovakia, 2015; pp. 1-42. ISBN 978-3-87-429492-8.

31. Guisinger, M.M.; Kuehl, J.V.; Boore, J.L.; Jansen, R.K. Extreme reconfiguration of plastid genomes in the angiosperm family Geraniaceae: Rearrangements, repeats, and codon usage. Mol. Biol. Evol. 2011, 28, 583-600. [CrossRef] [PubMed]

32. Kato, T.; Kaneko, T.; Sato, S.; Nakamura, Y.; Tabata, S. Complete structure of the chloroplast genome of a legume, Lotus japonicus. DNA Res. 2000, 7, 323-330. [CrossRef] [PubMed]

33. Guo, X.; Castillo-Ramírez, S.; González, V.; Bustos, P.; Luís Fernández-Vázquez, J.; Santamaría, R.; Arellano, J.; Cevallos, M.A.; Dávila, G. Rapid evolutionary change of common bean (Phaseolus vulgaris L) plastome, and the genomic diversification of legume chloroplasts. BMC Genom. 2007, 8, 228. [CrossRef] [PubMed]

34. Cai, Z.; Guisinger, M.; Kim, H.G.; Ruck, E.; Blazier, J.C.; McMurtry, V.; Kuehl, J.V.; Boore, J.; Jansen, R.K. Extensive reorganization of the plastid genome of Trifolium subterraneum (Fabaceae) is associated with numerous repeated sequences and novel DNA insertions. J. Mol. Evol. 2008, 67, 696-704. [CrossRef] [PubMed]

35. Jansen, R.K.; Wojciechowski, M.F.; Sanniyasi, E.; Lee, S.B.; Daniell, H. Complete plastid genome sequence of the chickpea (Cicer arietinum) and the phylogenetic distribution of rps12 and clpP intron losses among legumes (Leguminosae). Mol. Phylogenet. Evol. 2008, 48, 1204-1217. [CrossRef] [PubMed]

36. Palmer, J.D.; Singh, G.P.; Pillay, D.T.N. Structure and sequence evolution of three chloroplast DNAs. Mol. Gen. Genet. 1983, 190, 13-19. [CrossRef] 
37. Spielmann, A.; Ortiz, W.; Stutz, E. The soybean chloroplast genome: Construction of a circular restriction site map and location of DNA regions encoding the genes for rRNAs, the large subunit of the ribulose-1,5-bisphosphate carboxylase and the $32 \mathrm{KD}$ protein of the photosystem II reaction c. MGG Mol. Gen. Genet. 1983, 190, 5-12. [CrossRef]

38. Kaila, T.; Chaduvla, P.K.; Saxena, S.; Bahadur, K.; Gahukar, S.J.; Chaudhury, A.; Sharma, T.R.; Singh, N.K.; Gaikwad, K. Chloroplast genome equence of Pigeonpea (Cajanus cajan (L.) Millspaugh) and Cajanus scarabaeoides (L.) Thouars: Genome organization and comparison with other legumes. Front. Plant Sci. 2016, 7, 1-16. [CrossRef] [PubMed]

39. Doyle, J.J.; Doyle, J.L.; Palmer, J.D. Multiple independent losses of two genes and one intron from legume chloroplast genomes. Syst. Bot. 1995, 20, 272-294. [CrossRef]

40. Gantt, J.S.; Baldauf, S.L.; Calie, P.J.; Weeden, N.F.; Palmer, J.D. Transfer of $r p l 22$ to the nucleus greatly preceded its loss from the chloroplast and involved the gain of an intron. EMBO J. 1991, 10, 3073-3078. [PubMed]

41. Magee, A.M.; Aspinall, S.; Rice, D.W.; Cusack, B.P.; Semon, M.; Perry, A.S.; Stefanovic, S.; Milbourne, D.; Barth, S.; Palmer, J.D.; et al. Localized hypermutation and associated gene losses in legume chloroplast genomes. Genome Res. 2010, 20, 1700-1710. [CrossRef] [PubMed]

42. Hiratsuka, J.; Shimada, H.; Whittier, R.; Ishibashi, T.; Sakamoto, M.; Mori, M.; Kondo, C.; Honji, Y.; Sun, C.R.; Meng, B.Y.; et al. The complete sequence of the rice (Oryza sativa) chloroplast genome: Intermolecular recombination between distinct tRNA genes accounts for a major plastid DNA inversion during the evolution of the cereals. MGG Mol. Gen. Genet. 1989, 217, 185-194. [CrossRef] [PubMed]

43. Maier, R.M.; Neckermann, K.; Igloi, G.L.; Kössel, H. Complete sequence of the maize chloroplast genome: Gene content, hotspots of divergence and fine tuning of genetic information by transcript editing. J. Mol. Biol. 1995, 251, 614-628. [CrossRef] [PubMed]

44. Thomas, F.; Massenet, O.; Dorne, A.M.; Briat, J.F.; Mache, R. Expression of the $r p l 23$, rpl2, and rps19 genes in spinach chloroplasts. Nucleic Acids Res. 1988, 16, 2461-2472. [CrossRef] [PubMed]

45. Shinozaki, K.; Ohme, M.; Tanaka, M.; Wakasugi, T.; Hayashida, N.; Matsubayashi, T.; Zaita, N.; Chunwongse, J.; Obokata, J.; Yamaguchi-Shinozaki, K.; et al. The complete nucleotide sequence of the tobacco chloroplast genome: Its gene organization and expression. EMBO J. 1986, 5, 2043-2049. [CrossRef] [PubMed]

46. Ohyama, K.; Fukuzawa, H.; Kohchi, T.; Shirai, H.; Sano, T.; Sano, S.; Umesono, K.; Shiki, Y.; Takeuchi, M.; Chang, Z.; et al. Chloroplast gene organization deduced from complete sequence of liverwort Marchantia polymorpha chloroplast DNA. Nature 1986, 322, 572-574. [CrossRef]

47. Birky, C.W. The inheritance of genes in mitochondria and chloroplasts: Laws, Mechanisms, and Models. Annu. Rev. Genet. 2001, 35, 125-148. [CrossRef] [PubMed]

48. Corriveau, J.L.; Coleman, A.W.; Corriveau, J.L.; Coleman, A.W. Rapid screening method to detect potential biparental inheritance of plastid DNA and results for over 200 angiosperm species. Am. J. Bot. 2009, 75, 1443-1458. [CrossRef]

49. Zhang, Q.; Liu, Y. Sodmergen Examination of the cytoplasmic DNA in male reproductive cells to determine the potential for cytoplasmic inheritance in 295 angiosperm species. Plant Cell Physiol. 2003, 44, 941-951. [CrossRef] [PubMed]

50. Provan, J.; Powell, W.; Hollingsworth, P.M. Chloroplast microsatellites: New tools for studies in plant ecology and evolution. Trends Ecol. Evol. 2001, 16, 142-147. [CrossRef]

51. Ravi, V.; Khurana, J.P.; Tyagi, A.K.; Khurana, P. An update on chloroplast genomes. Plant Syst. Evol. 2008, 271, 101-122. [CrossRef]

52. Wolfe, K.H.; Li, W.H.; Sharp, P.M. Rates of nucleotide substitution vary greatly among plant mitochondrial, chloroplast, and nuclear DNAs. Proc. Natl. Acad. Sci. USA 1987, 84, 9054-9058. [CrossRef] [PubMed]

53. Daniell, H.; Lin, C.S.; Yu, M.; Chang, W.J. Chloroplast genomes: Diversity, evolution, and applications in genetic engineering. Genome Biol. 2016, 17, 134. [CrossRef] [PubMed]

54. Dhingra, A.; Folta, K.M. ASAP: Amplification, sequencing \& annotation of plastomes. BMC Genom. 2005, 6, 176. [CrossRef]

55. Cronn, R.; Liston, A.; Parks, M.; Gernandt, D.S.; Shen, R.; Mockler, T. Multiplex sequencing of plant chloroplast genomes using Solexa sequencing-by-synthesis technology. Nucleic Acids Res. 2008, 36. [CrossRef] [PubMed] 
56. Dong, W.; Xu, C.; Cheng, T.; Lin, K.; Zhou, S. Sequencing angiosperm plastid genomes made easy: A complete set of universal primers and a case study on the phylogeny of saxifragales. Genome Biol. Evol. 2013, 5, 989-997. [CrossRef] [PubMed]

57. McPherson, H.; van der Merwe, M.; Delaney, S.K.; Edwards, M.A.; Henry, R.J.; McIntosh, E.; Rymer, P.D.; Milner, M.L.; Siow, J.; Rossetto, M. Capturing chloroplast variation for molecular ecology studies: A simple next generation sequencing approach applied to a rainforest tree. BMC Ecol. 2013, 13, 8. [CrossRef] [PubMed]

58. Velasco, R.; Zharkikh, A.; Troggio, M.; Cartwright, D.A.; Cestaro, A.; Pruss, D.; Pindo, M.; FitzGerald, L.M.; Vezzulli, S.; Reid, J.; et al. A high quality draft consensus sequence of the genome of a heterozygous grapevine variety. PLoS ONE 2007, 2, e1326. [CrossRef] [PubMed]

59. Moore, M.J.; Dhingra, A.; Soltis, P.S.; Shaw, R.; Farmerie, W.G.; Folta, K.M.; Soltis, D.E. Rapid and accurate pyrosequencing of angiosperm plastid genomes. BMC Plant Biol. 2006, 6, 17. [CrossRef] [PubMed]

60. Jordan, W.C.; Courtney, M.W.; Neigel, J.E. Low Levels of Intraspecific Genetic Variation at a Rapidly Evolving Chloroplast DNA Locus in North American Duckweeds (Lemnaceae). Am. J. Bot. 1996, 83, 430-439. [CrossRef]

61. Uthaipaisanwong, P.; Chanprasert, J.; Shearman, J.R.; Sangsrakru, D.; Yoocha, T.; Jomchai, N.; Jantasuriyarat, C.; Tragoonrung, S.; Tangphatsornruang, S. Characterization of the chloroplast genome sequence of oil palm (Elaeis guineensis Jacq). Gene 2012, 500, 172-180. [CrossRef] [PubMed]

62. Yang, H.; Wei, C.L.; Liu, H.W.; Wu, J.L.; Li, Z.G.; Zhang, L.; Jian, J.B.; Li, Y.Y.; Tai, Y.L.; Zhang, J.; et al. Genetic divergence between Camellia sinensis and its wild relatives revealed via genome-wide SNPs from RAD sequencing. PLoS ONE 2016, 11, e0151424. [CrossRef] [PubMed]

63. Bakker, F.T.; Lei, D.; Yu, J.; Mohammadin, S.; Wei, Z.; van de Kerke, S.; Gravendeel, B.; Nieuwenhuis, M.; Staats, M.; Alquezar-Planas, D.E.; et al. Herbarium genomics: Plastome sequence assembly from a range of herbarium specimens using an iterative organelle genome assembly pipeline. Biol. J. Linn. Soc. 2016, 117, 33-43. [CrossRef]

64. Bock, D.G.; Kane, N.C.; Ebert, D.P.; Rieseberg, L.H. Genome skimming reveals the origin of the Jerusalem Artichoke tuber crop species: Neither from Jerusalem nor an artichoke. New Phytol. 2014, 201, 1021-1030. [CrossRef] [PubMed]

65. Wu, J.; Liu, B.; Cheng, F.; Ramchiary, N.; Choi, S.R.; Lim, Y.P.; Wang, X.W. Sequencing of chloroplast genome using whole cellular DNA and Solexa sequencing technology. Front. Plant Sci. 2012, 3, 1-8. [CrossRef] [PubMed]

66. Lin, C.S.; Chen, J.J.W.; Huang, Y.; Chan, M.; Daniell, H.; Chang, W.; Hsu, C.; Liao, D.C.; Wu, F.; Lin, S.; et al. The location and translocation of $n d h$ genes of chloroplast origin in the Orchidaceae family. Sci. Rep. 2015, 5, 9040. [CrossRef] [PubMed]

67. Pan, I.C.; Liao, D.C.; Wu, F.H.; Daniell, H.; Singh, N.D.; Chang, C.; Shih, M.C.; Chan, M.T.; Lin, C.S. Complete chloroplast genome sequence of an orchid model plant candidate: Erycina pusilla apply in tropical oncidium breeding. PLoS ONE 2012, 7, e34738. [CrossRef] [PubMed]

68. Kirti, P.B.; Narasimhulu, S.B.; Mohapatra, T.; Prakash, S.; Chopra, V.L. Correction of chlorophyll deficiency in alloplasmic male sterile Brassica juncea through recombination between chloroplast genomes. Gen. Res. 1993, 62, 11-14. [CrossRef]

69. Wyman, S.K.; Jansen, R.K.; Boore, J.L. Automatic annotation of organellar genomes with DOGMA. Bioinformatics 2004, 20, 3252-3255. [CrossRef] [PubMed]

70. Lowe, T.M.; Eddy, S.R. TRNAscan-SE: A program for improved detection of transfer RNA genes in genomic sequence. Nucleic Acids Res. 1996, 25, 955-964. [CrossRef]

71. Frazer, K.A.; Pachter, L.; Poliakov, A.; Rubin, E.M.; Dubchak, I. VISTA: Computational tools for comparative genomics. Nucleic Acids Res. 2004, 32, 273-279. [CrossRef] [PubMed]

72. Darling, A.C.E.; Mau, B.; Blattner, F.R.; Perna, N.T. Mauve: Multiple alignment of conserved genomic sequence with rearrangements mauve: Multiple alignment of conserved genomic sequence with rearrangements. Genome Res. 2004, 14, 1394-1403. [CrossRef] [PubMed]

73. DNA/RNA Base Composition Calculator. Available online: http://www.currentprotocols.com/WileyCDA/ CurPro3Tool/toolId-7.html (accessed on 16 April 2017).

74. MISA-MIcroSAtellite identification tool. Available online: http://pgrc.ipk-gatersleben.de/misa/ (accessed on 16 April 2017). 
75. Saski, C.; Lee, S.B.; Daniell, H.; Wood, T.C.; Tomkins, J.; Kim, H.G.; Jansen, R.K. Complete chloroplast genome sequence of Glycine max and comparative analyses with other legume genomes. Plant Mol. Biol. 2005, 59, 309-322. [CrossRef] [PubMed]

76. Tangphatsornruang, S.; Sangsrakru, D.; Chanprasert, J.; Uthaipaisanwong, P.; Yoocha, T.; Jomchai, N.; Tragoonrung, S. The chloroplast genome sequence of mungbean (Vigna radiata) determined by high-throughput pyrosequencing: Structural organization and phylogenetic relationships. DNA Res. 2010, 17, 11-22. [CrossRef] [PubMed]

77. Tsudzuki, J.; Ito, S.; Tsudzuki, T.; Wakasugi, T.; Sugiura, M. A new gene encoding tRNAPro (GGG) is present in the chloroplast genome of black pine: A compilation of 32 tRNA genes from black pine chloroplasts. Curr. Genet. 1994, 26, 153-158. [CrossRef] [PubMed]

78. Yao, X.; Tang, P.; Li, Z.; Li, D.; Liu, Y.; Huang, H. The first complete chloroplast genome sequences in Actinidiaceae: Genome structure and comparative analysis. PLoS ONE 2015, 10, e0129347. [CrossRef] [PubMed]

79. Kazakoff, S.H.; Imelfort, M.; Edwards, D.; Koehorst, J.; Biswas, B.; Batley, J.; Scott, P.T.; Gresshoff, P.M. Capturing the Biofuel Wellhead and Powerhouse: The Chloroplast and Mitochondrial Genomes of the Leguminous Feedstock Tree Pongamia pinnata. PLoS ONE 2012, 7, e51687. [CrossRef] [PubMed]

80. Yang, Y.; Dang, Y.; Li, Q.; Lu, J.; Li, X.; Wang, Y. Complete chloroplast genome sequence of poisonous and medicinal plant Datura stramonium: Organizations and implications for genetic engineering. PLoS ONE 2014, 9, e110656. [CrossRef] [PubMed]

81. Yan, L.; Lai, X.; Li, X.; Wei, C.; Tan, X.; Zhang, Y. Analyses of the complete genome and gene expression of chloroplast of sweet potato [Ipomoea batata]. PLoS ONE 2015, 10, e0124083. [CrossRef] [PubMed]

82. Huang, Y.; Matzke, A.J.M.; Matzke, M. Complete sequence and comparative analysis of the chloroplast genome of coconut palm (Cocos nucifera). PLoS ONE 2013, 8, e74736. [CrossRef] [PubMed]

83. Salim, H.M.W.; Cavalcanti, A.R.O. Factors influencing codon usage bias in genomes. J. Braz. Chem. Soc. 2008, 19, 257-262. [CrossRef]

84. Lee, J.; Kang, Y.; Shin, S.C.; Park, H.; Lee, H. Combined analysis of the chloroplast genome and transcriptome of the Antarctic vascular plant Deschampsia antarctica desv. PLoS ONE 2014, 9, e92501. [CrossRef] [PubMed]

85. Campbell, W.H.; Gowri, G. Codon Usage in Higher Plants, Green Algae, and Cyanobacteria. Plant Physiol. 1990, 92, 1-11. [CrossRef] [PubMed]

86. Daniell, H.; Wurdack, K.J.; Kanagaraj, A.; Lee, S.B.; Saski, C.; Jansen, R.K. The complete nucleotide sequence of the cassava (Manihot esculenta) chloroplast genome and the evolution of atpF in Malpighiales: RNA editing and multiple losses of a group II intron. Theor. Appl. Genet. 2008, 116, 723-737. [CrossRef] [PubMed]

87. Downie, S.R.; Olmstead, R.G.; Zurawski, G.; Soltis, D.E.; Soltis, P.S.; Watson, J.C.; Palmer, J.D. Six independent losses of the chloroplast DNA rpl2 intron in dicotyledons: Molecular and phylogenetic implications. Evolution 1991, 45, 1245-1259. [CrossRef] [PubMed]

88. Jansen, R.K.; Saski, C.; Lee, S.B.; Hansen, A.K.; Daniell, H. Complete plastid genome sequences of three rosids (Castanea, Prunus, Theobroma): Evidence for at least two independent transfers of rpl22 to the nucleus. Mol. Biol. Evol. 2011, 28, 835-847. [CrossRef] [PubMed]

89. Millen, R.S. Many parallel losses of infA from chloroplast DNA during angiosperm evolution with multiple independent transfers to the nucleus. Plant Cell 2001, 13, 645-658. [CrossRef] [PubMed]

90. Cusack, B.P.; Wolfe, K.H. When gene marriages don't work out: Divorce by subfunctionalization. Trends Genet. 2007, 23, 270-272. [CrossRef] [PubMed]

91. Ueda, M.; Fujimoto, M.; Arimura, S.I.; Murata, J.; Tsutsumi, N.; Kadowaki, K.I. Loss of the rpl32 gene from the chloroplast genome and subsequent acquisition of a preexisting transit peptide within the nuclear gene in Populus. Gene 2007, 402, 51-56. [CrossRef] [PubMed]

92. Ueda, M.; Nishikawa, T.; Fujimoto, M.; Takanashi, H.; Arimura, S.I.; Tsutsumi, N.; Kadowaki, K.I. Substitution of the gene for chloroplast RPS16 was assisted by generation of a dual targeting signal. Mol. Biol. Evol. 2008, 25, 1566-1575. [CrossRef] [PubMed]

93. Roy, S.; Ueda, M.; Kadowaki, K.; Tsutsumi, N. Different status of the gene for ribosomal protein S16 in the chloroplast genome during evolution of the genus Arabidopsis and closely related species. Genes Genet. Syst. 2010, 85, 319-326. [CrossRef] [PubMed]

94. Palmer, J.D.; Osorio, B.; Thompson, W.F. Evolutionary significance of inversions in legume chloroplast DNAs. Curr. Genet. 1988, 14, 65-74. [CrossRef]

95. Palmer, J.D. Chloroplast DNA exists in two orientations. Nature 1983, 301, 92-93. [CrossRef] 
96. Lavin, M.; Doyle, J.J.; Palmer, J.D. Evolutionary significance of the loss of the chloroplast-DNA inverted repeat in the leguminosae subfamily papilionoideae. Evolution 1990, 44, 390-402. [CrossRef] [PubMed]

97. Palmer, J.D.; Osorio, B.; Aldrich, J.; Thompson, W.F. Chloroplast DNA evolution among legumes: Loss of a large inverted repeat occurred prior to other sequence rearrangements. Curr. Genet. 1987, 11, 275-286. [CrossRef]

98. Cronk, Q.; Ojeda, I.; Pennington, R.T. Legume comparative genomics: Progress in phylogenetics and phylogenomics. Curr. Opin. Plant Biol. 2006, 9, 99-103. [CrossRef] [PubMed]

99. Bruneau, A.; Doyle, J.J.; Palmer, J.D. A Chloroplast DNA Inversion as a Subtribal Character in the Phaseoleae (Leguminosae). Syst. Bot. 1990, 15, 378-386. [CrossRef]

100. Khakhlova, O.; Bock, R. Elimination of deleterious mutations in plastid genomes by gene conversion. Plant J. 2006, 46, 85-94. [CrossRef] [PubMed]

101. Palmer, J.D. Plastid chromosomes: Structure and evolution. In Molecular Biology of Plastids; Bogorad, L., Ed.; Academic Press: San Diego, CA, USA, 1991; pp. 5-53.

102. Chen, C.; Zhou, P.; Choi, Y.A.; Huang, S.; Gmitter, F.G. Mining and characterizing microsatellites from citrus ESTs. Theor. Appl. Genet. 2006, 112, 1248-1257. [CrossRef] [PubMed]

103. Lin, C.P.; Ko, C.Y.; Kuo, C.I.; Liu, M.S.; Schafleitner, R.; Chen, L.F.O. Transcriptional slippage and RNA editing increase the diversity of transcripts in chloroplasts: Insight from deep sequencing of Vigna radiata genome and transcriptome. PLoS ONE 2015, 10, e0129396. [CrossRef] [PubMed]

104. Curci, P.L.; Paola, D.D.; Danzi, D.; Vendramin, G.G.; Sonnante, G. Complete chloroplast genome of the multifunctional crop globe artichoke and comparison with other Asteraceae. PLoS ONE 2015, 10, e0120589. [CrossRef] [PubMed]

105. Ozyigit, I.I.; Dogan, I.; Filiz, E. In silico analysis of simple sequence repeats (SSRs) in chloroplast genomes of Glycine species. Plant Omics J. 2015, 8, 24-29.

106. Wheeler, G.L.; Dorman, H.E.; Buchanan, A.; Challagundla, L.; Wallace, L.E. A review of the prevalence, utility, and caveats of using chloroplast simple sequence repeats for studies of plant biology. Appl. Plant Sci. 2014, 2, 1400059. [CrossRef] [PubMed]

107. Yi, D.; Kim, K. Complete chloroplast genome sequences of important oilseed crop Sesamum indicum L. PLoS ONE 2012, 7, e35872. [CrossRef] [PubMed]

108. Huang, H.; Shi, C.; Liu, Y.; Mao, S.; Gao, L. Thirteen Camellia chloroplast genome sequences determined by high-throughput sequencin: Genome structure and phylogenetic relationships. BMC Evol. Boil. 2014, 14, 151. [CrossRef]

109. Mariotti, R.; Cultrera, N.G.M.; Díez, C.M.; Baldoni, L.; Rubini, A. Identification of new polymorphic regions and differentiation of cultivated olives (Olea europaea L.) through plastome sequence comparison. BMC Plant Boil. 2010, 10, 211. [CrossRef] [PubMed]

110. Dong, W.; Liu, J.; Yu, J.; Wang, L.; Zhou, S. Highly variable chloroplast markers for evaluating plant phylogeny at low taxonomic levels and for DNA barcoding. PLoS ONE 2012, 7, e35071. [CrossRef] [PubMed] 